\title{
ENFRENTAMENTO E RECUSA DO FENÔMENO BUROCRÁTICO NO MAIO DE 68
}

RESUMO: O objetivo do presente texto é analisar o enfrentamento e a recusa das organizações burocráticas por parte do movimento estudantil e do movimento operário no contexto do Maio de 68 francês. Focaliza-se especialmente o enfrentamento às medidas burocráticas e contrarrevolucionárias do Partido Comunista Francês (PCF) e da Central Geral do Trabalho (CGT). Para tanto, seguiremos o seguinte itinerário: (1) breve apresentação do contexto e das determinações do Maio de 68 francês, (2) o papel do movimento estudantil (3) o papel do movimento operário; (4) o papel contrarrevolucionário da burocracia na experiência francesa, focalizando o PCF e CGT; (4) recusa da burocracia por setores do movimento estudantil e do movimento operário; (5) considerações finais.

Palavras-chave: Burocracia. Maio de 68. Movimento Estudantil. Revolução.

\section{COURSE AND REFUSAL OF THE BUREAUCRATIC PHENOMENON ON MAY 68}

ABSTRACT: The aim of this paper is to analyze the confrontation and refusal of bureaucratic organizations by the student movement and the labor movement in the context of the French May 1968. Particularly focused is the confrontation with the bureaucratic and counterrevolutionary measures of the French Communist Party (PCF) and the General Labor Office (CGT). To do so, we will follow the following itinerary: (1) brief presentation of the context and determinations of the French May 1968, (2) the role of the student movement (3) the role of the labor movement; (4) the counterrevolutionary role of bureaucracy in the French experience, focusing on the PCF and CGT; (4) denial of bureaucracy by sectors of the student movement and the labor movement; (5) final considerations.

Keywords: Bureaucracy. May 68. Student Movement. Revolution.

\footnotetext{
${ }^{1}$ Mestrando em Sociologia pelo Programa de Pós-Graduação de Sociologia da Universidade Federal de Goiás (PPGS/UFG). Endereço eletrônico: teles.gabriel@gmail.com.
} 


\section{ENFRENTAMIENTO Y DENEGACIÓN DEL FENÓMENO BUROCRÁTICO EN EL MAYO DE 68}

RESUMEN: El objetivo del presente texto es analizar el enfrentamiento y el rechazo de las organizaciones burocráticas por parte del movimiento estudiantil y del movimiento obrero en el contexto del Mayo del 68 francés. Se enfoca especialmente el enfrentamiento a las medidas burocráticas y contrarrevolucionarias del Partido Comunista Francés (PCF) y de la Central General del Trabajo (CGT). Por lo tanto, seguir el siguiente calendario: (1) una breve presentación de las determinaciones de contexto y mayo 68 francés, (2) el papel del movimiento estudiantil (3) el papel del movimiento obrero; (4) el papel contrarrevolucionario de la burocracia en la experiencia francesa, centrándose en el PCF y CGT; (4) rechaza la burocracia por sectores del movimiento estudiantil y del movimiento obrero; (5) consideraciones finales.

Palavras Clave: Burocracia. Mayo de 68. Movimiento Estudiantil. Revolución.

\section{Introdução}

A humanidade só será feliz no dia em que o último burocrata for enforcado com as tripas do último capitalista (escrita em paredes da Universidade de Sorbonne, Maio de 68)

O ano de 2018 nos presenteia com a comemoração de 50 anos de uma das experiências mais impactantes do século XX: o Maio de 68. Meio século é um período de tempo já significativo para voltarmos, de modo crítico e atento, a uma das tentativas de radicalização das lutas, tanto operárias, quanto estudantis, que sacudiram o mundo. Lutas estas que ameaçaram a própria manutenção da ordem capitalista francesa e, resguardando seus limites, do modo de produção capitalista em geral, dado o seu caráter internacional graças à crise de acumulação de capital enfrentada naquele período.

A distância temporal nos auxilia e permite não cairmos em dois problemas de possibilidades de análise desta experiência: o primeiro é a percepção superficial do calor do momento, onde não temos controle e nem tempo para analisar as múltiplas determinações do fenômeno. Isso porque o envolvimento pode ser tamanho que ignoramos alguns elementos que só poderão ser compreendidos dali em diante, quando a história nos mostrar nossos erros, o desconhecimento de determinadas forças políticas, os desdobramentos históricos, etc ${ }^{2}$.

\footnotetext{
${ }^{2}$ Maurice Brinton nos alertara sobre esta questão já no calor do momento, em junho de 1968: "Uma análise completa dos eventos na França terá eventualmente que ser empreendida, uma vez que sem um entendimento da sociedade moderna, nunca será possível mudá-la conscientemente. Mas essa análise terá de esperar até a poeira baixar. [...] os verdadeiros eventos de 1968 terão então de ser integrados em um novo arcabouço de idéias" (SOLIDARITY, 2008, p.14).
} 
Já o segundo problema consiste no distanciamento do ponto de vista da historicidade do capitalismo. Maio de 68 representou também o sintoma da crise do capitalismo oligopolista transnacional, que se tornou hegemônico desde o fim da Segunda Guerra Mundial. Trata-se da crise do regime de acumulação conjugado. Após seu fim, anos depois, um novo regime da acumulação se inicia, com novos elementos, novas formas de dominação derivados dela ${ }^{3}$, etc. Nesse sentido, já em outro momento do desenvolvimento do capitalismo, podemos ter uma ideia melhor do que estava passando naquele período histórico. Esse distanciamento nos possibilita almejar, enfim, uma melhor análise a partir da totalidade das relações dali derivadas.

No entanto, ao mesmo tempo, a distância de meio século traz perigos que precisam ser anunciados possivelmente de forma mais perigosa ainda: o esquecimento e a deformação. Esquecimento do que existia de mais revolucionário e a deformação dos acontecimentos históricos, à luz de determinados interesses alheios aos que buscavam contribuir com a transformação social naquela época. Maio de 68, como qualquer experiência onde as lutas são radicalizadas, traz consigo uma enorme gama de interpretações e análises que não expressam a sua realidade concreta. E o tempo, com a força das ideias dominantes, contribuem para o perecimento do seu conteúdo radical e revolucionário. Nesse sentido, a classe dominante e suas classes auxiliares (sobretudo a intelectualidade e a burocracia) buscam, paulatinamente, meios de ofuscar a chama revolucionária ali acendida, despolitizando-a e transformando-a em um mero "café descafeinado".

Desse modo, a distância temporal nos fornece, tal qual uma faca de dois gumes, uma oportunidade e um desafio. A oportunidade de perceber o valor histórico e o desafio em enfrentar as interpretações contrarrevolucionárias e conservadoras acerca desta experiência autogestionária. Em nossa perspectiva, não basta apenas descrever os eventos desencadeados em Maio de 68. É necessário desnudá-lo em suas múltiplas determinações, efetivando um processo analítico que dê conta não só de resgatar os acontecimentos daquele período, mas também de refletir sobre eles e explicitar seu significado para as lutas de classes, bem como para a possibilidade da constituição de uma nova sociedade via destruição do capitalismo.

É com essas premissas que buscamos contribuir para a análise do Maio de 68. Ao nosso ver, a experiência francesa foi uma das mais frutíferas e radicais que estourou no mundo naquele período de crise e contestação generalizada. Foi na França, especialmente em

\footnotetext{
${ }^{3}$ E é exatamente nesse novo regime de acumulação a qual, contemporaneamente, nos encontramos; aquilo que chamam, capitalismo neoliberal, de regime de acumulação flexível (HARVEY, 1992) ou, como preferimos, regime de acumulação integral (VIANA, 2009).
} 
Paris e suas cidades satélites, que a síntese de um mundo em efervescência, onde as lutas de classes se intensificaram, se desaguaram de forma mais cristalina e nítida. O presente trabalho tem, portanto, foco e recorte: o Maio de 68 francês. Mas não se trata, aqui, de trazer um panorama histórico desta experiência, nem um trabalho de fôlego que consiga articular todas as determinações postas antes, durante e após esta experiência (já que impossível esgotá-las em um pequeno texto como este). Assim, buscamos trazer uma das características e elementos mais importantes observados, tendo consequência tanto para a classe operária, quanto para o movimento estudantil: a recusa, consciente e sistemática, da burocracia e de suas organizações derivadas.

Em Maio de 68 houve um processo de recusa às velhas e tradicionais organizações burocráticas, como os partidos e sindicatos. Não apenas a recusa "prática", mas também teórica. Retoma-se a crítica à burocracia e todas as consequências derivadas dessa concepção. Tal recusa e crítica não se deu apenas por indivíduos isolados ou pequenos grupos marginalizados, mas também de forma generalizada, tornando uma ideia e prática hegemônica no interior da agitação e ocupações do movimento estudantil, e das ocupações e greves do movimento operário francês. A negação dessas organizações, que buscavam controlar e dirigir aos moldes burocráticos, veio simultaneamente a um momento de afirmação: o processo de início de autogestão das lutas operárias (especialmente no fim de maio e início de junho) e da auto-organização estudantil. E é justamente estes elementos que confere a essa experiência, dentro de outras determinações, a sua condição de revolucionária.

Por esse ângulo, o objetivo deste trabalho é analisar o enfrentamento e a recusa das organizações burocráticas por parte do movimento estudantil e do movimento operário no contexto do Maio de 68 francês. Devido ao espaço, focalizaremos especialmente o enfrentamento às medidas burocráticas e contrarrevolucionárias do Partido Comunista Francês (PCF) e da Central Geral do Trabalho (CGT).

Para tanto, seguiremos o seguinte itinerário: (1) breve apresentação do contexto e das determinações do Maio de 68 francês, (2) o papel do movimento estudantil (3) o papel do movimento operário; (4) o papel contrarrevolucionário da burocracia na experiência francesa, focalizando o PCF e CGT; (4) recusa da burocracia por setores do movimento estudantil e do movimento operário.

\section{Contexto e Elementos Históricos: o Maio de 68 francês}


Uma análise sobre um fenômeno concreto que não perceba a sua totalidade é uma análise insuficiente ou incompleta. Marx já dizia que o concreto é a síntese de múltiplas determinações (MARX, 2008), sendo uma de suas características a historicidade ${ }^{4}$. Isso significa que os fenômenos são constituídos, e não "dados”, ou seja, empíricos, como alguns denominam. A partir deste ponto de partida, só podemos compreender o Maio de 68 a partir de sua reconstituição histórica, que é uma totalidade. Essa totalidade, por sua vez, está inserida em uma totalidade mais ampla: a sociedade capitalista. Assim, pensar na dinâmica histórica do Maio de 68 sem relacioná-la com a dinâmica da sociedade capitalista é um procedimento insuficiente e ideológico ${ }^{5}$.

Não podemos trazer aqui todos os elementos que desencadearam o Maio de 68, mas podemos evidenciar a sua determinação fundamental: a crise do regime de acumulação que assolava o capitalismo daquela época. Do ponto de vista histórico, a época do Maio de 68 correspondia aos últimos suspiros daquilo que Nildo Viana (2009) chama de regime de acumulação conjugado (e que Harvey [1992], ideologicamente, chama de regime de acumulação fordista) - fase do desenvolvimento histórico que o modo de produção capitalista estava passando naquela época. A era da acumulação conjugada se estabeleceu no mundo pós-Segunda Guerra mundial e tinha como elementos fundamentais o fordismo, enquanto processo de valorização hegemônico; a sua forma estatal integracionista (o que alguns chamam de Estado "bem-estar social"); e o imperialismo transnacional (VIANA, 2009).

Com a crise desse regime de acumulação, entre a década de 60 e 70, a partir de sua dificuldade em resolver a tendência da queda da taxa de lucro; os conflitos sociais postos pelas lutas de classes daquele período, etc., trouxeram descontentamentos e contestações em vários lugares do mundo ${ }^{6}$. Na crise desse regime de acumulação, longe de ser sentida de forma homogênea, cada país se viu acometido de maneiras distintas e, por consequência, a reação dos explorados não fora igualmente homogênea.

Não é mera casualidade que a década de 60, especialmente a sua segunda metade, seja denominada, por muitos de seus pesquisadores e militantes, como "década do conflito"7. No

\footnotetext{
${ }^{4}$ Historicidade entendida enquanto uma categoria do método dialético, um recurso heurístico do marxismo.

${ }^{5}$ No sentido que Marx e Engels (2007) concebiam essa expressão: enquanto falsa consciência sistematizada.

${ }^{6}$ Para análises pormenorizadas acerca do esgotamento deste regime de acumulação ver Cf. HARVEY, 1992; VIANA, 2009; BIHR, 2010.

${ }^{7}$ No entanto, a grande maioria dos "analistas", pesquisadores, etc., não conseguiram desvendar os motivos desta onda massiva de conflitos. Cada qual se agarrava a uma determinação isolada, sem visualizar a totalidade da
} 
mundo insurgiram conflitos dos mais diversos possíveis, tanto nos países de capitalismo subordinado ("3 mundo", países "em desenvolvimento", etc.), quanto nos países de capitalismo imperialista (países de "capitalismo desenvolvido", capitalismo “central”, etc.), bem como no bloco dos países de capitalismo estatal ("socialismo real") influenciados e subordinados pela União Soviética (URSS). Nesse sentido, podemos ver conflitos, antes mesmo do 68 francês, nos Estados Unidos da América (EUA), Japão, Alemanha, Itália, Brasil, México, Leste Europeu, China, Vietnã, Argélia, etc.

Isto significa que as lutas de classes se intensificaram, de modos distintos e específicos de acordo com cada país, em todo o globo. E o Maio de 68 pode ser considerado um dos conflitos internacionalizados mais significativos da história do capitalismo. A expansão da miséria e da exploração capitalista traz, em seu bojo, também a expansão da resistência e da contestação. Tratemos agora das consequências da crise do regime de acumulação conjugado no contexto francês, foco de nosso trabalho.

A França se constituía enquanto um dos países de capitalismo imperialista com maior abertura e porosidade para o estado integracionista, sendo um dos modelos de sucesso econômico para aquele período. Após a Segunda Guerra Mundial, nos 20 anos que se seguiram, mais da metade dos camponeses franceses deixaram suas terras e migraram para o espaço urbano, onde, juntamente com os trabalhadores imigrantes (especialmente das excolônias francesas na África) anexaram-se às fileiras das classes trabalhadoras (SCHWARZ, 2008), especialmente da classe operária.

\begin{abstract}
Após o fim da Guerra da Argélia, em 1962, a economia francesa cresce rapidamente. A perda de suas colônias força a burguesia francesa a orientar sua economia mais fortemente em direção à Europa. Em 1957, a França já havia assinado o Tratado de Roma, documento fundador da Comunidade Econômica Européia, antecessora da União Europeia. A integração econômica da Europa favorece a construção de novos ramos da indústria, que compensam o declínio das minas de carvão e de outras velhas indústrias além do esperado. Na área de automóveis, aeronaves, tecnologia espacial, armamentos e energia nuclear, com o apoio do governo abrem-se novas fábricas e companhias (SCHWARZ, 2008, s/p).
\end{abstract}

Com essa nova formatação produtiva, a França "moderniza" seu capitalismo e disputa, junto com os EUA, a Alemanha e o Japão, um dos postos de potência "econômica" capitalista. Com o envolvimento maior de tecnologia na cadeia produtiva, cresce a necessidade da força de trabalho especializada em maior escala: engenheiros, técnicos, trabalhadores especializados, burocratas empresariais, etc.

sociedade e seus rumos apontados. Nesse sentido, constituem como ideologias que mais contribuem para ofuscar a realidade e, portanto, contribuem para a resolução dos conflitos para o lado da classe dominante. 
Além disso, com o estado integracionista, o número de serviços públicos estatais, ou ligados à dinâmica institucional, cresce exponencialmente; a consequência disso é, igualmente, o crescimento exponencial da burocracia estatal e civil. Todo esse processo requisitará um maior número de força de trabalho especializada e qualificada. As universidades, fonte de produção desse tipo força de trabalho, possuem um papel fundamental nesse processo. Mas, ao mesmo tempo, elas também começam a passar por profundas mudanças que afetarão sua estrutura e orientação educacional. João Bernardo (2008) nos fornece uma destas mudanças no interior do espaço universitário.

O desenvolvimento do capitalismo, com as pressões para o aumento da produtividade e, portanto, com a necessidade de qualificar a força de trabalho, converteu universidades de elite em universidades de massa e transformou a maioria dos estudantes universitários em futuros trabalhadores (BERNARDO, 2008, p. 22).

Assim, o autor trata da mudança de orientação das Universidades, que se tornaram verdadeiras fábricas de produção de novos burocratas e especialistas para dar conta do desenvolvimento da acumulação de capital. No entanto, esse processo não se deu só na França: todos os países de capitalismo imperialista, devido à necessidade daquele contexto, tiveram essa mudança. E isso, evidentemente, trouxe modificações na orientação ideológica, reproduzidas pelo espaço acadêmico.

No entanto, há também uma mudança importante no contexto universitário francês: explode o número de $\operatorname{vagas}^{8}$ para o ingresso na educação superior. Em 1956 a França possuía 207 mil universitários matriculados; um número, para época, já expressivo, sendo um dos países com o maior número de universitários do mundo. Dez anos depois, este número cresce em 143\%, saltando para 505 mil universitários em 1967 (BACHY \& BACHY, 1973, p. 21). As consequências também são sentidas no âmbito da educação secundária e na própria composição social e dinâmica das classes sociais na França.

No entanto, passada sua "fase de ouro", o regime de acumulação conjugado começa a ruir em meados da década de 1960 e esse processo traz consequências diretas e graves ao capitalismo francês. O Maio de 68 francês só é clarificado se tivermos em conta esse processo, já que há implicações tanto para os estudantes, quanto para a classe operária e demais trabalhadores assalariados.

\footnotetext{
${ }^{8}$ Mandel também coloca que o aumento de número de vagas foi feito também em outros países de capitalismo imperialista: "A explosão universitária a que assistimos ainda hoje foi, pois, consequência de uma procura fortemente acrescida e de uma oferta não menos fortemente aumentada de mão-de-obra intelectual" (MANDEL, 1979, p. 42).
} 
Groppo (2005) coloca também outros acontecimentos, antecedentes a 68, que contribuíram para o aprofundamento e intensificação das lutas de classes daquele período:

Em maio de 68, além do mais, houve uma reunião dramática de recentes questões nacionais francesas: a ascensão do general de Gaulle, em 1958, da qual o Poder Executivo pareceu sair exageradamente fortalecido em torno de um regime personalista; a traumática solução das questões coloniais francesas, com o fim da Guerra da Argélia e uma passiva posição quanto ao início da Guerra do Vietnã; e o avanço de outro bastião do poder político social na França, o Partido Comunista Francês (PCF), que desejava a conquista do poder nas eleições de 1972 (GROPPO, 2005, p. 213).

\title{
3. O Movimento Estudantil no Maio de 68
}

Como pudemos evidenciar, havia um contexto favorável para a radicalização da luta de classes na França ${ }^{9}$. Mas como se deu o processo revolucionário do Maio de 68 ? Primeiro o apresentaremos no contexto estudantil, já que foram os estudantes que deram início ao processo de contestação e, posteriormente, no do movimento operário.

O contexto de crise afeta as políticas de educação francesa. Diversas medidas são tomadas para conter os gastos públicos. É o que nos mostra, sinteticamente, Viana:

\begin{abstract}
Neste contexto, o novo regime de acumulação e suas bases começam a se desgastar e junto com isso a situação do ensino superior começa a se deteriorar devido ao crescimento enorme do número de estudantes universitários aliado à pouca perspectiva de inserção futura no mercado de trabalho. A situação do capitalismo francês em declínio provocou a busca da reforma universitária através do Plano Fouchet e do V Plano (MANDEL, 1979), segundo a qual a qualidade do ensino, a condição estudantil, ficava prejudicada. Aliada a isso, a perspectiva de desemprego após o término dos estudos era outra preocupação existente, o que trazia não só a recusa da ressocialização e do futuro ethos de adulto, mas também até a falta de perspectiva de inserção no mercado de trabalho. A precarização da condição estudantil era motivo de insatisfação adicional dos jovens, já descontentes com o processo de ressocialização e tendo que viver esta em situação precária e submetidos a uma reforma universitária apontando para a criação de uma universidade tecnocrática (VIANA, 2015, p. 117).
\end{abstract}

O estopim para a contestação juvenil inicia-se na Universidade de Nanterre, não por mero acaso. Nanterre fora construída em 1964 em um contexto do boom do crescente número de vagas universitárias para suprir a demanda de força de trabalho especializada. A cinco quilômetros de Paris, localiza-se em uma das regiões mais pobres e desvalorizadas da cidade (chamadas de "bidonvilles ${ }^{10 "), ~ r o d e a d a ~ p o r ~ u m ~ g r a n d e ~ e ~ e x p r e s s i v o ~ c o m p l e x o ~ i n d u s t r i a l ~ e ~}$ fabril (SCHWARZ, 2008).

\footnotetext{
${ }^{9}$ Não esquecemos, também, que França sempre teve um histórico de experiência revolucionárias e uma intensa agitação revolucionária ao longo de sua história. As revoluções de 1848, Comuna de Paris, etc.

${ }^{10}$ Em tradução livre, seria o equivalente a "favela" no português. 
Em contexto de crise, Nanterre e as demais universidades "marginalizadas", são as primeiras atingidas pelos cortes na educação e pela repressão posterior à contestação. No início do ano de 1968, estudantes de Nanterre protestam contra a Guerra do Vietnã ${ }^{11}$ e o caráter passível do governo francês sobre esta questão. A resposta do Estado e da burocracia universitária é a repressão: diversas medidas disciplinares, repetidas intervenções policiais e a detenção de alguns estudantes, intensificam ainda mais o descontentamento e a contestação. A resposta dos estudantes vem no dia 22 de março, que se torna, inclusive, o nome de uma organização política estudantil que terá grande importância nos acontecimentos seguintes:

No dia 22 de março de 1968, quatro membros do grupo de Cohn-Bendit foram presos ao pregar cartazes. Depois da manifestação que se seguiu à prisão, com a invasão de cerca de 150 estudantes à sede administrativa da universidade, o grupo foi batizado com a data desse protesto, 22 de Março, símbolo início da luta naquela cidade (GROPPO, 2005, p. 216).

Groppo fala em "invasão", mas o que se desenrolou naquele contexto foi, na verdade, uma ocupação. Nesse sentido, a ocupação de Nanterre se constituiu como a primeira ocupação e primeira ação radicalizada dos estudantes contra a repressão do Estado e da burocracia universitária. Com a rápida generalização das ocupações da faculdade dessa Universidade, e o massivo apoio do corpo docente e discente, a reitoria manda fechar por um mês o espaço universitário. Essa medida acaba dando maior visibilidade às demandas dos estudantes, o que trará consequências no sentido de se espalhar para outras universidades.

Com a ocupação da Sorbonne ${ }^{12}$ em maio, o movimento estudantil, a partir de suas demandas, começou a ter enorme visibilidade, já que esta universidade, com tradições de vários séculos, possuía um grande valor simbólico cultural francês. Em 3 de maio, a CRS ${ }^{13}$ (Companhia Republicana de Segurança) invade esta universidade a mando do reitor (Paul Roche) e do ministro da educação (Alain Peyrefitte). A repressão é brutal: muitos estudantes presos, espancados e alguns deles, os mais conhecidos, sumariamente condenados. A consequência dessa ação é colocada por Brinton:

\footnotetext{
${ }^{11}$ Os protestos contra a Guerra do Vietnã (empreendida pelos Estados Unidos contra o Vietnã do Norte) terão lugar privilegiado nas lutas estudantis da década de 60. Em janeiro de 1968, os norte-americanos começam a "Ofensiva Tet", o que faz explodir muitas revoltas e manifestações contrárias no mundo todo. É deste acontecimento que se trata a manifestação de Nanterre.

12 “A Sorbonne foi repentinamente transformada de um antiquado recinto onde o capitalismo francês selecionava e moldava seus hierarcas, seus tecnocratas e sua burocracia administrativa, em um vulcão revolucionário em plena erupção, cuja lava se espalharia longe e amplamente, cauterizando a estrutura social na França Moderna" (SOLIDARITY, 2005, p. 38).
}

${ }^{13}$ Atual Polícia Nacional (Police Nationale). 


\begin{abstract}
A inacreditável - embora inteiramente previsível - incompetência desta "solução" burocrática para o "problema" do descontentamento estudantil precipitou uma reação em cadeira. Ela despertou a raiva, o ressentimento e a frustração de dezenas de milhares de jovens que possuíam agora um motivo para uma ação futura, além de um objetivo alcançável. Os estudantes, despejados da universidade, tomaram as ruas, reivindicando a libertação de seus companheiros, a reabertura de suas faculdades, a remoção dos policiais. Levas e levas de novas pessoas logo entraram na luta. O sindicato estudantil (UNEF) e o sindicato dos professores das universidades (SNESup) convocaram uma greve por tempo indeterminado. Durante uma semana os estudantes defenderam suas ideias em manifestações de rua cada vez maiores e mais militantes. No dia 7 de maio, terça-feira, 50 mil estudantes e professores marcharam pelas ruas (SOLIDARITY, 2008, p. 16).
\end{abstract}

É neste contexto que ocorre a famosa Noite das Barricadas, onde estudantes e apoiadores enfrentaram a repressão policial durante toda a madrugada do dia 10 para o dia 11 de maio. "A batalha estendeu-se até as 6 horas da manhã do 11 . Com 367 feridos, 460 presos e 180 carros destruídos” (GROPPO, 2005, p. 222). Apesar da brutal repressão, não conseguiram retirar os estudantes das ruas que se defendiam em dezenas de barricas ${ }^{14}$ espalhadas pelo Quartier Latin ${ }^{15}$. Dias depois, mais de um milhão de pessoas foram às ruas em solidariedade aos estudantes e contra o governo. Entre os estudantes havia uma clara consciência da necessidade de suas lutas se estenderem para além do meio universitário e para além de demandas estudantis.

Havia uma profunda consciência de que o problema não poderia ser resolvido no Quartier Latin, que o isolamento da revolta em um "gueto" estudantil (mesmo que um "gueto" autônomo) significaria a derrota. Eles compreendem que a salvação do movimento reside na sua extensão a outros setores populares (SOLIDARITY, 2008, p. 20).

Conscientemente, setores estudantis radicalizados que, naquele momento, possuíam hegemonia entre os estudantes no geral, convocaram e estabeleceram que suas lutas deveriam se aliar às lutas histórica do movimento operário. Começava, então, uma luta cultural para a aliança estudantil-operária se efetivar. É nesse momento que o movimento operário é ingresso no Maio de 68 - trataremos desta questão agora.

\title{
4. O Movimento Operário no Maio de 68
}

O ingresso do movimento operário no conflito se deu a partir de uma greve geral, de 24 horas, puxada pelas centrais sindicais francesas e encabeçada fundamentalmente pela CGT

\footnotetext{
14 “Todos faziam alguma coisa, ainda que não soubessem exatamente o que e para que. Na Rua Gay Lussac foram construídas dez barricas, uma atrás da outra. Isso não tinha nenhum significado militar, apenas tínhamos vontade de fazer barricadas" (COHN-BENDIT, 1988, p. 41).

${ }^{15}$ Quartier Latin é um bairro parisiense que fica à margem do Rio Sena, em torno da Universidade de Sorbonne. 
(Confederação Geral do Trabalho), entre os dias 13 e 14 de maio, constrangidos pela erupção estudantil. No entanto, apesar das centrais sindicais reforçarem a ideia de ser uma greve de um dia (e deixaremos isso mais claro nos próximos tópicos), o que se viu foi uma generalizada e simultânea greve, com ocupações de fábricas nunca antes vista na história francesa. Independentes dos sindicatos, os trabalhadores começaram a ocupar fábricas, cruzar os braços em greves e manter contato direto com os estudantes que buscam uma aliança com eles.

No dia 17 de maio havia 200 mil grevistas; já no dia seguinte, 1 milhão, e mais de 50 fábricas ocupadas. Em menos de uma semana o número chegou aos expressivos 10 milhões de trabalhadores em greve; uma verdadeira e autêntica greve geral que literalmente parou a França. A maioria dos liceus foi fechada, os trabalhadores do transporte "público" (coletivo) paralisaram, além dos demais serviços de uso comum: "os aeroportos, táxis, metrô, rádios, televisões, jornais, correios, telefone e setores do comércio começaram a parar também" (GROPPO, 2005, p. 224). Já no interior do movimento operário a força da greve é enorme: 94,8\% dos trabalhadores do setor automobilístico entram em greve; 94,2\% na indústria têxtil e 91,8\% nos setores de combustíveis, minérios, gás, eletricidade, água, etc. (ADAM, 1970).

No entanto o significado histórico e revolucionário desta experiência não se encontra em seus números ou em dados estatísticos de quantas pessoas aderiram ou não às mobilizações daquele período. Maurício Tragtenberg (2008) já nos alertara que o caráter anticapitalista e autogestionário da luta pela transformação social não se dá tão somente a partir de determinadas reivindicações (e acrescentamos: nem do número de indivíduos), mas sim, fundamentalmente, no fato do movimento operário, em seu processo de luta, constituir organizações autárquicas (auto-organizadas), igualitárias, criando, assim, uma nova sociabilidade, a autogestão de suas lutas rumo à autogestão da sociedade. No caso do movimento estudantil, enquanto um movimento social específico, por não possuir um projeto alternativo de sociedade próprio, o caráter revolucionário se dá na articulação de suas reivindicações com as do movimento operário.

Devido à sua impossibilidade de promover, por si mesma, a revolução social, então a juventude busca se aproximar do proletariado para conseguir concretizar o projeto autogestionário. A união do proletariado e da juventude gera, por sua vez, uma fusão que abre espaço para a possibilidade concreta da autogestão, pois a transformação das relações de produção e a ação juvenil no interior das demais relações sociais criam o clima favorável para aglutinar os demais setores descontentes da sociedade e garantir uma hegemonia do projeto autogestionário. Esse foi o processo que se iniciou no final da década de 1960 e quase se concretizou no Maio de 1968 em Paris (VIANA, 2015, p. 155-116). 
A radicalização das lutas estudantil-operárias não se deu apenas devido ao descontentamento por parte desses setores da sociedade, mas também devido ao acúmulo histórico já esboçado pelo movimento operário e pelos revolucionários que o apoiaram. É precisamente nessa época que autores marxistas voltam a ser lidos e debatidos (Marx, Rosa Luxemburgo, comunistas de conselhos); o anarquismo ressurge; as teses do grupo em torno da revista Socialismo ou Barbárie começam a ter expressiva influência; e a Internacional Situacionista adquire um papel importante no bojo do processo revolucionário. Enfim, uma cultura contestadora (VIANA, 2015) é resgatada, desenvolvida e posta em ação por estudantes e trabalhadores na França de 68.

No interior das ocupações universitárias, a palavra de ordem será autogestão. Inclusive é neste período que esta palavra adquire outro significado ${ }^{16}$ para expressar o conteúdo revolucionário do proletariado e distanciar do caráter burocrático dos partidos “comunistas" e do leninismo (GUILHERM \& BOURDET, 1976).

\begin{abstract}
A confusa aspiração de maio de 1968 em substituir um centralismo opressivo, de origem jacobina e uma burocracia todo-poderosa, própria do modelo socialista tradicional, por organismos políticos e econômicos descentralizados no qual seria lícito a cada um assumir de novo sua existência total, tomar conta do seu próprio destino, em uma palavra, "significar" uma vida que se fez absurda, vai em busca de uma doutrina global que pode traduzi-la em termos claros; e a esse respeito a autogestão se presta maravilhosamente (ARVON, 1982, p. 38).
\end{abstract}

Maurice Brinton (2008, p. 48), por exemplo, coloca o caráter de abolição do objetivo da universidade no capitalismo pelos estudantes em Maio de 68: “Aqueles que participaram na Sorbonne não devotaram seus esforços para uma mera reorganização do sistema educacional, mas a uma total subversão da sociedade". Abriram a universidade para o restante da sociedade de forma que todos pudessem participar e todos tivessem o mesmo peso em encaminhamentos das assembleias. Primeiro chegaram delegados de outras universidades ocupadas, depois as dos colégios secundaristas, e, por fim, os delegados de trabalhadores.

Dia após dia o pátio e os corredores permanecem abarrotados, num fluxo bidirecional para todas as partes imagináveis do enorme prédio. [...] Uma nova

\footnotetext{
${ }^{16}$ Segundo Guilherm e Bourdet (1976), a palavra autogestão em francês apareceu no início dos anos 60 para expressar a experiência Iugoslávia de Tito. É a tradução literal da palavra servo-croata "samoupravje) (samo = "auto"; upravlje = "gestão"). No entanto, ela será ressignificada, segundo Viana: "a gênese francesa da palavra lhe atribui um significado novo. Esse 'significado novo' significa, no fundo, unir o signo e o ser da autogestão, união inexistente anteriormente, pois o ser, o projeto utópico de uma nova sociedade fundada na autoorganização geral da sociedade, já existia, bem como uma palavra que expressa isso (entre outras, como anarquia, comunismo, sistema de conselhos, autogoverno dos produtores, indivíduos livremente associados, etc.) emerge posteriormente, mas significando algo mais restrito (cogestão de empresas) e é num determinado contexto da luta de classes que o ser e o signo se unificam" (VIANA, 2013, p. 16).
} 
estrutura está gradualmente sendo construída. [...] As salas são distribuídas para o Comitê de Ocupação, para o Comitê de Imprensa, para o Comitê de Propaganda, para os comitês de aliança estudantes/trabalhadores, para os comitês que tratam de estudantes estrangeiros, para os comitês de ação dos secundaristas, para o comitê que trata da distribuição do espaço físico, e para as inúmeras comissões que se encarregam de projetos tais como a produção de um dossiê sobre as atrocidades policias, o estudo das implicações da autonomia, do sistema de avaliação etc. Qualquer um procurando com o que se ocupar pode prontamente encontrar algo para fazer (SOLIDARITY, 2008, p. 48).

Esse tipo de organização e o caráter revolucionário das ações estudantis não se concentravam apenas na Sorbonne, mas na quase totalidade das universidades ocupadas. Isso expressa o caráter hegemônico que esses setores estudantis possuíam no Maio de 68. Brinton, novamente, nos dá outro exemplo com a ocupação do "Centre Censier" (um prédio da nova Faculdade de Letras da Universidade de Paris):

\begin{abstract}
Logo após o Censier ser ocupado, um grupo de ativistas controlou uma grande parte do terceiro piso. Esse espaço seria a sede dos então propostas "comitês de ação trabalhador-estudante". A ideia geral era estabelecer laços com grupos de trabalhadores, por menores que fossem, que compartilhassem a visão revolucionária-libertária desse grupo de estudantes. [...] O que uniu os companheiros do Censier foi a nítida percepção das potencialidades revolucionárias da situação e o entendimento de que não tinham tempo a perder. [...] Quais eram suas ideias? [...] um rápido e autônomo desenvolvimento da luta da classe trabalhadora, a organização de comitês de greve eleitos que fizessem a ligação entre os sindicalizados e não-sindicalizados em todas as empresas e indústrias em greve, reuniões regulares dos grevistas de modo que as decisões fundamentais permanecessem nas mãos do trabalhador comum, comitês de defesa dos trabalhadores para defender os piquetes das intimidações da política, um diálogo constante com os estudantes revolucionários com o objetivo de restituir à classe trabalhadora sua própria tradição de democracia direta e sua própria aspiração à autogestão, que foi usurpada pelos burocratas dos sindicatos e partidos políticos (SOLIDARITY, 2008, p. 50).
\end{abstract}

Em síntese, o significado histórico de Maio de 68 é constituído ao buscarmos e resgatarmos a autogestão de suas lutas, tanto estudantis, inicialmente, quanto operárias, em menor grau, posteriormente.

No entanto, ressaltamos aqui apenas uma parte dessa experiência. A experiência francesa, como já dissemos, só pode ser compreendida a partir da totalidade de seu evento. Com a intensificação de suas lutas, as classes sociais se apresentam de forma mais clara, evidenciando seus interesses imediatos e históricos. Até agora, ressaltamos, fundamentalmente, a classe operária, no desenvolvimento de suas lutas, e a burguesia, que buscava reprimir e acabar com as revoltas estudantis e a radicalização das lutas operárias.

É necessário explicitar o papel de outra classe social que possui papel fundamental na reprodução do modo de produção capitalista e que, em seus setores marginalizados, buscam se autonomizar e tomar o poder do Estado para si. Trata-se da burocracia. Não teremos espaço 
para desenvolver a nossa concepção de burocracia. Por isso nos limitaremos a apontar algumas de suas características e determinações, bem como uma determinada fração desta classe e organizações que efetivaram um papel no interior do Maio de 68, que é o foco deste trabalho: O PCF (Partido Comunista Francês) e a CGT (Confederação Geral do Trabalho).

\section{A Burocracia e o seu papel no Maio de 68}

A nossa compreensão de burocracia é marxista, ou seja, a compreendemos tanto como uma forma organizacional, quanto como uma classe social.

A burocracia é uma forma organizacional caracterizada pela relação entre dirigentes
e dirigidos, instituída, legitimada e estruturada por normas escritas (regimentos, leis,
etc.), cujo funcionamento ocorre via meios formais de admissão e relações
hierárquicas (divisão de cargos e atribuições) nas quais o quadro dirigente (os
burocratas) é assalariado e possui a posse dos meios de administração e o poder de
decisão, sendo que sua função social é o exercício do controle, da dominação,
processo predeterminado pelo modo de produção capitalista (VIANA, 2015, p. 265).

Nesse sentido, uma determinada organização burocrática visa realizar uma determinada ação que é geralmente de controle, dominação, etc. O quadro dirigente das organizações burocráticas constitui uma classe social: a burocracia. No entanto, a visão mais comum que se tem sobre a burocracia é a visão leninista, ou seja, a compreende enquanto uma camada social e não como classe. Lênin possui uma visão economicista das classes sociais no capitalismo, reduzindo sua definição no que ele compreende por "sistema de produção" (CUEVA, 1974). Esta definição é distinta da concepção marxista, que coloca a questão das atividades fixadas pela divisão social do trabalho, gerando um modo de vida em comum, trazendo interesses e oposições de classe em comum (MARX \& ENGELS, 2002; VIANA, 2012).

Com a experiência da Revolução Russa e sua derrota a partir da contrarrevolução burocrática, tornou-se mais claro o caráter de classe da burocracia. Makhaiski (1981), intelectual russo, foi um dos primeiros a perceber esse processo a partir da expressão intelligentsia. Posteriormente a ele, e com o desenvolvimento da burocracia, tanto nos países de capitalismo privado, quanto nos países de capitalismo estatal (onde a burocracia se funde com a burguesia), a percepção da burocracia enquanto classe social vai se tornando cada vez mais desenvolvida e clarificada.

$\mathrm{Na}$ França, por exemplo, Cornelius Castoriadis e Claude Lefort, a partir do grupo e revista Socialismo ou Barbárie buscaram explicitar o caráter classista da burocracia no antigo 
regime da URSS ${ }^{17}$, chamando-a de "capitalismo burocrático" (CASTORIADIS, 1983). Além disso, a Internacional Situacionista denunciou a burocracia no interior da experiência soviética que se desenvolvera no que eles também chamavam de capitalismo burocrático (INTERNACIONAL SITUACIONISTA, 2002; DEBORD, 1997; JAPPE, 2008). E tanto o grupo Socialismo e Barbárie, quanto a Internacional Situacionista exercerão grande influência na recusa das burocracias no Maio de 68 .

Como colocamos no início deste texto, um dos elementos mais característicos e importantes do Maio de 68 foi, por parte dos estudantes mais radicalizados, a recusa e a crítica desapiedada às burocracias de quaisquer tipos. Tanto a estatal, que representa a fração de classe mais próxima à burguesia, por estar no controle da principal máquina de regularização da sociedade capitalista; quanto suas frações inferiores, a partir dos partidos comunistas, socialistas, etc., que buscavam controlar o movimento operário e tomar o poder do Estado $^{18}$.

O partido comunista francês e a CGT (central sindical), ligados e subordinados ao capitalismo soviético, possuíam uma influência em declínio tanto no interior do movimento estudantil, quanto no movimento operário. Isso se explica pela desilusão do grupo estudantil e da classe operária em relação a estas organizações burocráticas, dada às suas ações subordinadas aos interesses dos soviéticos, mas também às medidas contrarrevolucionárias apoiadas pela URSS (como no caso da Guerra Civil na Argélia) e o acúmulo de uma cultura contestadora na França. Diante deste contexto, quais foram as respostas e medidas postas por essas burocracias ao longo do Maio de 68 ?

Com uma fraca influência no interior do grupo estudantil, o Partido Comunista Francês, irá observar, de longe, ou a partir de suas correias de transmissão que são as “juventudes comunistas”, a radicalização do movimento estudantil no início de Maio, à época das primeiras ocupações e manifestações. O cerne dessa radicalização se dava na forma autoorganizada em que os estudantes se organizavam e nas demandas que extrapolavam a questão estudantil e educacional. E isto, evidentemente, não poderia ser tolerado pelo partido.

\footnotetext{
${ }^{17}$ Apesar da crítica, os militantes da revista possuíam uma concepção administrativista da burocracia.

${ }^{18}$ Lênin é o grande ideólogo dessa fração marginalizada da burocracia: "Lênin representa a classe burocrática; a tentativa dessa classe de se autonomizar radicalizando a sua prática, seu modo de vida (a atividade de direção) e seu interesse de classe fundamental: aumentar o número e a necessidade da burocracia na totalidade da sociedade (burocratização). O leninismo, por consequência, representa uma ideologia de um determinado setor da burocracia (sobretudo as frações inferiores). É expressão da tentativa de modernização estatizante do capitalismo. Para conseguir tal autonomia, com objetivo de tomar o poder do Estado, o leninismo fala em nome do proletariado, buscando dirigi-lo e dominá-lo; as experiências históricas do começo do século XX nos alerta como esse processo pode ocorrer" (TELES; FERREIRA, 2017, p. 84).
} 
Inicialmente, buscaram ignorar as mobilizações estudantis. O silêncio poderia ser uma arma, pois logo poderia acabar no esquecimento e tudo poderia voltar a normalidade. Mas as mobilizações não só cresceram em tamanho, mas também radicalizaram ainda mais. Era necessário, portanto, se posicionar.

É por isso que uma das principais armas de ataque da burocracia partidária e também sindical foi a partir dos seus jornais, sobretudo o l'Humanité. Em 8 de maio, o secretariado do Partido se expressa nesse jornal da seguinte forma:

O descontentamento dos estudantes é legítimo. Mas a situação favorece atividades aventureiras, cujas concepções políticas não oferecem perspectiva aos estudantes e não possuem nada em comum com uma política verdadeira progressista e de longo prazo [...] (L’HUMANITÉ apud SOLIDARY, 2008, p. 67).

Obviamente que a "política verdadeiramente progressista e de longo prazo" só seria aquela dirigida e controlada pela cúpula burocrática (comitê central) do partido, a partir de moldes burocráticos e contrarrevolucionários. Nesta mesma edição do jornal, o secretáriogeral da UEC (Union des Étudiants Communistes) - juventude "comunista" ligado ao Partido -, Jean-Michel Catala, escreve:

[...] as ações de grupos irresponsáveis estão ajudando os poderes estabelecidos a alcançarem seus objetivos [...] O que devemos fazer é pedir um orçamento educacional maior, que assegure maiores subvenções aos estudantes, a nomeação de mais professores e com melhores qualificações, a construção de novas faculdades [...] (L'HUMANITÉ apud SOLIDARITY, 2008, p. 67).

A necessidade de manter os estudantes em suas reinvindicações imediatas significa reproduzir os fundamentos que fazem existir a própria condição estudantil e suas mazelas derivadas. Nesse sentido, a intenção da UEC era a de que os estudantes se conformassem a essa perspectiva e que eles, enquanto "sindicato estudantil", dirigiriam e mediariam o conflito estudantil. Enquanto o movimento estudantil estava avançando, a UEC, obedecendo as diretrizes do Partido, buscava recuar, limitar, enfim, parar o avanço revolucionário dos estudantes.

Nos acervos documentais consultados, tanto o partido quanto o sindicato buscavam meios de neutralizar o movimento estudantil que começara a ter ressonância no seio do movimento operário. Por falta de argumentos, partiram para adjetivações pejorativas, comuns no meio burocrático para desqualificar o inimigo ${ }^{19}$. Assim, os estudantes radicalizados eram taxados de "aventureiros", pequeno-burgueses, contrarrevolucionários, lacaios à serviço do

${ }^{19}$ Lênin foi um dos pioneiros a buscar vencer debates a partir de adjetivações. O exemplo clássico é o seu livro (LENIN, 2014) "Esquerdismo, doença infantil do comunismo". 
imperialismo e do governo, anticomunistas, etc. Outro exemplo pode ser dado a partir da declaração dos professores da Sorbonne ligados ao Partido Comunista:

\begin{abstract}
Os professores comunistas exigem a libertação dos estudantes presos e a reabertura da Sorbonne. Cientes de nossas responsabilidades, especificamos que esta solidariedade não significa que concordamos ou apoiamos os lemas de certas organizações estudantis. Nós desaprovamos os lemas fantasiosos, demagógicos e anticomunistas, e os métodos de ação irresponsáveis defendidos por vários grupos de esquerda (L'HUMANITÉ apud SOLIDARITY, p. 66).
\end{abstract}

Era necessário, a todo custo, distanciar-se e evidenciar que o Partido não estava relacionado a estes "elementos subversivos". Uma das razões tornara-se óbvia posteriormente: esta burocracia partidária estava se preparando para as próximas eleições, em um programa comum com a recém-criada Fédération de la Gauche Démocrate et Socialiste (FGDS). Além disso, existia uma ordem da burocracia superior ligada a Moscou:

\begin{abstract}
Documentos secretos publicados posteriormente pelo Le Nouvel Observateur mostraram que o embaixador soviético na França manteve constante diálogo com esse partido, insistindo muito na necessidade de parar a perigosa mobilização, no que o PCF colaboraria, de novo obediente às diretivas de Moscou. [...] Afinal, além de ser uma revolta geracional e atrapalhar os planos eleitoreiros, o movimento era visto por Moscou como uma ameaça de ruptura da ordem geopolítica da Guerra Fria. [...] Era preciso pará-los, em nome dos interesses geopolíticos da União Soviética (GROPPO, 2005, p. 220).
\end{abstract}

No entanto, é a partir das primeiras tentativas de aliança entre movimento estudantil e movimento operário que o caráter burocrático, para além de escritos de jornais e conversas internas no interior dos partidos, sindicatos e organizações estudantis burocráticas, aparece de forma cristalizada. Assim, a ideia de convocar uma greve geral de 24 horas é sintomática, tendo em vista a sua efemeridade que, não ameaçando a ordem estabelecida, não encontrariam dificuldades em controlá-las. No dia 13 de Maio, após uma manchete que convocava a greve geral de um dia, segue a seguinte declaração do departamento político:

\footnotetext{
A união da classe trabalhadora e dos estudantes ameaça o regime. [...] Isto cria um enorme problema. É essencial que não seja permitida nenhuma provocação, nenhum desvio que distraia quaisquer das forças que lutam contra o regime ou que dêem ao governo o menor pretexto que seja para distorcer o significado dessa grande luta (L'HUMANITÉ apud SOLIDARITY, 67).
}

O entendimento aqui de "provocação" e "desvio" é de autonomia dos trabalhadores perante aos sindicatos, criando suas próprias organizações de base (comitê de fábrica, conselhos operários, etc.), ou a socialização com os estudantes revolucionários. Assim que os estudantes souberam da greve geral e das ocupações de fábricas (algumas delas já desvinculadas dos sindicatos), eles marcharam rumo a estas fábricas com o objetivo de prestar 
solidariedade, trocar experiências e buscar alianças. No entanto, temendo os estudantes, os sindicatos fecharam as portas das fábricas e impediram que os estudantes entrassem em contato com os trabalhadores:

Enquanto durou a greve geral os estudantes procuraram ligar-se aos trabalhadores e a direção da CGT esforçou-se por impedir esta ligação. A 16 de Maio cerca de mil estudantes dirigiram-se às grandes fábricas Renault de Billancourt, que haviam acabado de entrar em greve, e a CGT opôs-se a qualquer contacto dos estudantes com os trabalhadores argumentando que "recusamos qualquer ingerência externa". A solidariedade era apelidada de "ingerência" (BERNARDO, 2008, p. 29).

Os relatos e textos de Roger Gregoire e Fredy Perlman reunidos no livro "Comitês de ação dos trabalhadores e estudantes: França, maio de $68^{\prime 20}$ nos fornece algumas das manobras burocráticas que os sindicatos, especialmente a CGT, utilizara nas fábricas no contexto da greve geral. Uma destas manobras, a título de curiosidade, foi o controle absoluto do sistema de microfone de cada fábrica, ocupada e controlada por eles. Repetiam, tal como a imprensa burguesa, que os estudantes estavam preocupados com a qualidade do ensino e do sistema de provas, e os trabalhadores preocupados com o salário. Esperavam, com essa tática, isolar as lutas e limitá-las em questões imediatas, criando um ambiente propício aos seus objetivos, fazendo com que os trabalhadores menos instruídos ou desinformados acreditassem nessa desinformação.

O maior objetivo do sindicato era impedir as fábricas ocupadas de serem transformadas em espaços em que os trabalhadores pudessem expressar a si mesmos criativamente. Isso deveria ser feito, se possível, sem a intervenção da polícia, já que um ataque inoportuno da polícia durante a greve geral poderia levar os trabalhadores a começarem a se auto-organizar em autodefesa. O sindicato dirigiu essa operação logo após o despontar da greve. Oficiais do sindicato se colocaram na cabeça do "movimento"; eles controlaram todos os microfones e "iniciaram" a ocupação da fábrica; a burocracia do sindicato procedeu então a "ocupar" a fábrica no lugar dos trabalhadores. Dentro da fábrica ocupada pelo sindicato, ninguém podia se expressar: os oficiais do sindicato liam nos microfones discursos preparados para uma audiência composta amplamente por delegados do sindicato. Os trabalhadores dentro da fábrica não estavam muito entusiasmados com a "ocupação"; estes que não se entusiasmaram não aplaudiram os discursos lidos pelos oficiais nos microfones, e à noite eles foram ao Censier para analisar o que devia ser feito. [...] $\mathrm{O}$ próximo maior objetivo do sindicato era impedir contatos entre os trabalhadores e os estudantes, para impedir que a consciência do poder coletivo fluísse até as fábricas. Isso foi feito por uma combinação de propaganda e força. No nível da propaganda, foi dito aos trabalhadores que os problemas dos estudantes não tinham nada em comum com os problemas dos trabalhadores. [...] No nível da força: os trabalhadores foram trancados dentro, os estudantes foram trancados fora. A maioria dos trabalhadores, de fato, não estava dentro da fábrica, eles foram mantidos longe pelo fato de que nada acontecia lá; esses trabalhadores estavam em casa, ouvindo o governo no rádio, lendo a imprensa burguesa, e esperando o fim da greve; eles

${ }^{20}$ Cf. Disponível em português em: 〈https://libcom.org/library/comit\%C3\%AA-de-a\%C3\%A7\%C3\%A3o-detrabalhadores-e-estudantes $>$. Acesso em: 02/02/2018. 
foram afastados com segurança da possibilidade de se tornarem conscientes de qualquer coisa (GREGOIRE \& PERLMAN, 2017, p. 60-61).

Não só nas fábricas a CGT e o Partido Comunista Francês buscaram controlar os trabalhadores, mas também nas manifestações. No ato que se seguiu nas ruas de Paris, durante a "greve geral de um dia", organizado pelas burocracias, a tática foi tentar isolar os estudantes dos trabalhadores. Além disso, na noite anterior, um edital escrito e assinado pelos organizadores da manifestação (diversos sindicatos e partidos, além da CGT e do PCF) colocava que a única literatura permitida seria as produzidas e aceitas previamente pelos organizadores. Felizmente, com a enorme adesão da manifestação, não foi possível controlar os panfletos, jornais e revistas distribuídas nas manifestações. A "passeata", para as centrais sindicais e partidos, deveria ser ordeira e dispersar como planejado pelos organizadores. Maurice Brinton, sobre essa questão, escreve:

\begin{abstract}
A CGT está ávida que suas centenas de milhares de partidários dispersem pacificamente. Ela os teme quando eles estão juntos. Ela quer que eles voltem a ser átomos sem nome dispersos nos quatros cantos de Paris, impotentes no quadro de suas preocupações individuais. A CGT vê a si mesma como a única ligação possível entre eles, como veículo divinamente determinado para expressar o desejo coletivo deles. O "Movimento 22 de Março", por outro lado emitiu uma chamada aos estudantes e trabalhadores, pedindo que se mantivessem juntos e prosseguissem para os gramados do Champs de Mars (no pé da Torre Eiffel) para uma grande discussão coletiva sobre as experiências daquele dia e sobre os problemas que os esperam adiante. [...] Os que protestam contra as ordens de dispersão são imediatamente repreendidos e denunciados como "provocadores" pelos organizadores, que muitas vezes também empregam a força física contra eles (SOLIDARITY, 2008, p. 31-33).
\end{abstract}

Apesar de todo o esforço das burocracias, as greves e ocupações foram muito além de um dia. Como colocamos anteriormente, a França literalmente parou com mais de 10 milhões de trabalhadores em greve. Estouraram várias manifestações ao longo do mês de maio e junho, em sua grande maioria não convocadas pelas centrais sindicais e por partidos ditos comunistas ou socialistas.

\title{
6. Estudantes e Trabalhadores contra a Burocracia
}

A reação de determinados grupos estudantis e determinados setores de trabalhadores quanto às medidas e manobras burocráticas foram desapiedadas e duras. No seio do movimento estudantil, a crítica às burocracias partidárias e sindicais já existiam de longa data, influenciados por revolucionários diversos (Marx, Bakunin, Comunistas de Conselhos, Internacional Situacionista, etc.). Por isso que já no início das ações estudantis existia uma recusa, clara e sistemática, contra as burocracias que buscavam controlá-los. E por parte dos trabalhadores, igualmente existia, além de outras determinações, a recusa destas organizações 
burocráticas, mas ainda de forma confusa e menos intensa devido à hegemonia política dos sindicatos no interior determinadas fábricas. Em alguns setores do movimento operário, no entanto, o número de sindicalizados era pequeno, e, assim, conseguiu-se avançar em conjunto aos estudantes.

Talvez uma das frases mais famosas de Maio de 68 seja uma das que mais sintetizam a oposição às burocracias: A humanidade só será livre quando o último capitalista for enforcado nas tripas do último burocrata. Nela está explícita a síntese não apenas da oposição às burocracias, mas seu total antagonismo a elas, devido ao seu caráter contrarrevolucionário. Nas universidades ocupadas a maioria dos muros estampavam cartazes políticos de denúncia às burocracias. Grupos de estudos e debates acerca do caráter essencialmente burocráticos dos partidos e sindicatos foram formados (especialmente em Sorbonne, Nanterre e Censier) e a teoria revolucionária voltou a ser lida e transformada em armas nas mãos dos estudantes.

Por parte dos trabalhadores também surgiram ações em oposição e denúncia às burocracias, especialmente sindicais. Os trabalhadores da Rhone-Paulenc (atual Sanofi, indústria farmacêutica), em panfleto, colocaram:

\footnotetext{
Até agora tentamos resolver nossos problemas através de petições, de lutas parciais e da eleição de melhores líderes. Isso não nos levou a lugar algum. Ação dos estudantes nos mostrou que somente a ação dos que estão subordinados pode fazer as autoridades recuarem. [...] os estudantes estão se opondo totalmente às finalidades da educação burguesa. Eles querem que eles mesmos tomem as principais decisões. Nós também deveríamos. Deveríamos decidir a finalidade da produção, e sobre quem recairiam os custos da produção (RHONE-POULENC apud SOLIDARITY, 2008, p. 52-53).
}

Já um panfleto dos operários do setor automobilístico da Renault expressa o seguinte: “[...] sendo trabalhadores, deveríamos procurar controlar o funcionamento de nossa empresa. Nossos objetivos são similares aos dos estudantes. A gestão da indústria e a gestão da universidade deveriam ser realizadas democraticamente por aqueles que lá trabalham" (RENAULT apud SOLIDARITY, 2008, p. 52). Podemos citar, também, o panfleto dos trabalhadores da Air France: "[...] recusamos a continuar confiando nossas reivindicações a dirigentes sindicais profissionais. Como os estudantes, devemos tomar em nossas mãos o controle de nossas atividades" (AIR FRANCE apud SOLIDARITY, p. 52).

Enfim, como podemos notar, existia uma recusa às burocracias tanto por parte dos estudantes quanto de setores do movimento operário. Antes de prosseguirmos é necessário assinalar uma questão acerca da recusa à burocracia. Focamos aqui um determinado setor das frações da burocracia, o Partido Comunista Francês e a Confederação Geral do Trabalho. No 
entanto, isto não significa que somente este partido e este sindicato foram criticados e recusados no interior da experiência revolucionária do Maio de 68. O PCF e a CGT estavam ligados a uma orientação política stalinista, mas as outras "orientações", oriundas do bolchevismo e da ideologia leninista, como o trotskismo e o maoísmo ${ }^{21}$, foram também recusadas e criticadas.

É evidente, como já colocamos, que o movimento estudantil e o movimento operário não se constituíam como blocos homogêneos. Por esse ângulo, muitas organizações burocráticas participaram das mobilizações do Maio de 68 buscando hegemonia e controle desta experiência. Muitas delas criticavam as ações do Partido Comunista e da CGT não pelo modo de organização ou por seus objetivos essencialmente burocráticos, mas pelas escolhas e táticas equivocadas. Tudo se resumia à direção desacertada. Isso, evidentemente, faz parte das disputas interburocráticas oriundas da busca pelo poder ${ }^{22}$.

\section{O fim do Maio de 68: a burocracia, novamente, salva a burguesia}

O esgotamento do Maio de 68 começa a ser percebido pelos fins de maio e início de junho. A última cartada é posta: se os estudantes se aliaram com os trabalhadores, várias organizações burocráticas buscam se aliar à burguesia para deter a experiência revolucionária. Assim, às escondidas, é feito um acordo entre os sindicatos, as associações patronais e o governo. "No dia 27 [de maio], anunciaram-se as 'conquistas' para os trabalhadores em greve: $35 \%$ de aumento salarial, diminuição da semana de trabalho, mais direitos sindicais, pagamento normal pelos dias parados, etc.” (GROPPO, 2005, p. 226). No entanto, os trabalhadores, tendo consciência de sua força naquele momento, rejeitaram tais propostas.

A tática da CGT e do PCF, a partir deste momento, começa a mudar: agora buscavam fragmentar a luta nas negociações e nos acordos (BERNARDO, 2008). Essa medida começa a obter resultados, posto que um expressivo número de fábricas estava sob controle dos sindicatos.

\footnotetext{
${ }^{21}$ A revolução cultural chinesa teve um forte impacto no mundo. Assim, mesmo que de forma confusa, surge uma tendência maoísta esquerdista no interior dos acontecimentos do Maio de 68 francês. Na época, pouca informação se tinha sobre esse acontecimento, o que motivou uma ideia deformada dessa experiência que apontava para as disputas interburocráticas no interior do partido comunista chinês.

${ }^{22}$ Não podemos desenvolver o processo de recusa a estas outras organizações burocráticas, já que não é o nosso foco; mas podemos deixar algumas indicações de leitura de algumas obras que já foram utilizadas aqui e desenvolver melhor estas questões: o livro Paris: Maio de 68, editado pelo coletivo Solidarity e escrito por Maurice Brinton e a obra Comitê de Ação de Trabalhadores e Estudantes de Roger Gregoire e Fredy Perlman são materiais fundamentais que demonstram, sistemática e explicitamente a partir dos documentos elaborados pelos próprios estudantes e trabalhadores, esta recusa da burocracia.
} 
Presos dentro das fábricas por piqueteiros designados, que falam pelos oficiais do sindicato, informados por microfones e pela imprensa que os militantes lá fora são provocadores anarquistas que seguem um irresponsável Líder estrangeiro [trata-se de Cohn Bendit], os trabalhadores se tornam ainda mais dependentes. Presos em um contexto no qual todos os seus poderes são alienados, os trabalhadores veem suas possibilidades do ponto de vista da impotência - e desse ponto de vista, nada é possível e nada pode ser aprendido (GREGOIRE \& PERLMAN, 2017, p. 61).

Já algumas semanas parados, os trabalhadores sinalizam sinal de cansaço com a situação. De Gaulle, presidente da França, busca apoio de suas tropas do exército na Alemanha Ocidental e não descarta o uso das forças armadas. Em 30 de Maio, estrategicamente, De Gaulle pronuncia em rádio uma convocação para a participação, da população em geral, a um ato cívico contra a ameaça do comunismo; e mais de meio milhão de pessoas participam. A composição dos participantes desse ato, segundo Martins Filho (1996, p.106), era constituída por “jovens burgueses, políticos de renome, gordas camponesas, paraquedistas da Argélia vestidos com uniforme de combate". Enfim, o que era de mais reacionário e conservador na França ${ }^{23}$. Os estudantes buscaram reagir com uma manifestação no $1^{\circ}$ de junho; mas apenas 30 mil pessoas aparecem. À medida que os sindicatos conseguiam neutralizar a aliança entre os estudantes e os trabalhadores, as ocupações de fábrica e a greve refluíam dia por dia, até chegar a um ponto que se tornara perigoso continuar em greve ou ocupar a fábrica.

Nos locais onde os trabalhadores, desvinculados das burocracias, decidiram corajosamente resistir, às tropas da política, e até mesmo forças do Exército, foram usadas para expulsar à força os grevistas. Assim, paulatinamente, o movimento operário autodeterminado foi refluindo até voltar à normalidade do trabalho:

Por fim, os trabalhadores regressaram ao trabalho e a classe dominante concentrou novamente o poder em suas mãos. Quando o movimento começou a minguar, o Estado iniciou sua vingança. Houve incidentes violentos, sobretudo no dia 11 de junho com 400 feridos, 1.500 detidos e um manifestante morto com um tiro em Montbéliard. No dia seguinte, foram proibidas as manifestações na França, pouco depois, os estudantes foram expulsos do Odéon e, dois dias mais tarde, da Sorbonne.

23 "Algumas dezenas de milhares de apoiadores do governo se manifestaram desde a Concórdia até o Étoile. Foram realizadas manifestações similares de apoio ao governo em toda a França. Mas uma olhada mais atenta nas fotografias revelava imediatamente a verdadeira natureza dessas manifestações: prefeitos aposentados enrolados em faixas tricolores, cidadãos de classe média barrigudos, pensionistas e outras figuras parecidas indignadas e insatisfeitas com a sociedade. Basta comparar estas fotografias com as manifestações massivas do proletariado alguns dias antes para descobrir a verdadeira correlação de forças. Tudo de vivo, forte e vibrante da sociedade francesa se reuniu sob a bandeira da revolução, enquanto que tudo de opaco, velho e decadente estava do outro lado das barricadas. Um bom empurrão bastava para derrubar tudo. O que faltava era um golpe de misericórdia, mas este nunca foi dado" (WOODS, 2017, p. 117). 
Começou então a criminalização. Na cadeia estatal de rádio e televisão, ORTF, foram demitidos 102 jornalistas por suas atividades durante os acontecimentos. Enviaram a polícia às universidades de Nanterre e Sorbonne para controlar os documentos de identidade dos estudantes e não saíram de lá antes de 19 de dezembro. Foi aprovado um pacote de medidas de austeridade no dia 28 de novembro na Assembleia Nacional (WOODS, 2016, p. 116).

Além disso, 150 estrangeiros que teriam participado ativamente dos acontecimentos do Maio de 68 foram expulsos do país pelo governo, que também decretou o fechamento de 11 organizações de "extrema-esquerda", entre elas um dos mais famosos: o coletivo 22 de Março (GROPPO, 2008). Diante de todas essas medidas, o refluxo das lutas radicais foi eminente.

Georges Seguy (apud DEMENACH, 1968, p. 35), secretário-geral do CGT na época, afirmara com todas as letras que a CGT contribuiu para o estabelecimento da ordem e retomada do geral do trabalho: "A opinião pública perturbou-se com as confusões e as violências, desorientada pelas posições equivocadas e o abandono do Estado, de modo que a CGT, a grande força tranquila, é quem veio restabelecer a ordem ao organizar a retomada geral do trabalho". Além disso, João Bernardo nos fornece o balanço do Partido Comunista Francês:

\footnotetext{
O Partido Comunista Francês, que se havia oposto à movimentação contestatária e que em seguida disputara as eleições legislativas de 30 de junho reivindicando-se de ter sido o primeiro partido em França a denunciar o esquerdismo, viu-se condenado à irrelevância, ele que tanta importância havia tido e que fora hegemónico em boa parte da vida intelectual do país. Por seu lado, a CGT, se é certo que continua a ser a principal central sindical francesa, detém hoje esta posição numas circunstâncias em que só $8 \%$ da força de trabalho se encontra sindicalizada. A oposição dos comunistas franceses ao Maio de 68 condenou-os perante a esquerda anticapitalista, sem que a direita ordeira lhes agradecesse o serviço prestado (BERNARDO, 2008, p. 31).
}

Assim, não resta dúvida sobre a grande contribuição contrarrevolucionária do PCF e da CGT: a burocracia, novamente, salvou a burguesia do processo revolucionário dos explorados e oprimidos.

\section{Considerações Finais}

A experiência francesa de 1968 é prenhe de diversas interpretações. A deformação do seu real significado já tivera início em seu próprio desenvolvimento, no bojo dos seus acontecimentos. A deformação e a desinformação são fundamentais para aqueles que querem conservar e reproduzir a sociedade capitalista. Elas constituem verdadeiras armas nas mãos da burguesia e de suas classes auxiliares na trama da luta cultural e do processo da dinâmica das lutas de classes. 
O itinerário do presente texto demonstrou o caráter contrarrevolucionário do Partido Comunista Francês (PCF) e da Confederação Geral do Trabalho (CGT), duas organizações burocráticas que contribuíram para o amortecimento das lutas de classe e o emperramento do aprofundamento das formas de auto-organização dos trabalhadores. No entanto, para não restar dúvidas, é necessário relembrar o que já colocamos anteriormente: estas duas organizações são apenas duas organizações burocráticas que contribuíram para o não avanço da luta; diversas frações burocráticas, diversos partidos e sindicatos, buscaram, igualmente, ao seu modo, atrasar ou buscar a hegemonia do movimento para dirigi-los ao seu modo (maoístas, trotskistas, social-democracia, etc.).

Como diriam os estudantes franceses de Censier: a burocracia é a última trincheira do capitalismo. No século $\mathrm{XX}$, as experiências revolucionárias do proletariado (Revolução Russa, Alemã, Espanhola, Maio de 68, etc.) sempre encontraram a burocracia enquanto uma poderosa força a ser enfrentada. É exatamente por esse motivo que existe a necessidade de combatê-la. Assim, buscar intensificar a luta cultural contra essa classe e suas organizações torna-se fundamental para aqueles que almejam a transformação social e a emancipação humana via autoemancipação dos trabalhadores.

O Maio de 68 francês, longe de ser uma experiência não passível de crítica $^{24}$, demonstrou, novamente, ao mundo que o movimento operário é a classe revolucionária dos nossos tempos. A chama continua acesa: a emancipação dos trabalhadores será obra dos próprios trabalhadores.

\section{Referências}

ADAM, G. Étude statistique des gréves de mai-juin 1968. Revue française de science politique, v.20, n.1, p. 105-119, 1970.

ARVON, H. La Autogestion. 2a edição, México: Fondo de Cultura Económica, 1982.

BACHY C. \& BACHY, J-P. Les Étudians en la Politique. Paris: Armand Colin, 1973.

BERNARDO, J. Estudantes e Trabalhadores no Maio de 68. Revista Lutas Sociais, n.19/20, 2008.

BIRH, A. Da Grande Noite à Alternativa - O movimento operário europeu em crise. São Paulo: Boitempo, 2010.

\footnotetext{
${ }^{24}$ Buscaremos, em um outro trabalho, expor aquilo que compreendemos os limites e críticas acerca desta experiência histórica.
} 
CASTORIADIS, C. Socialismo ou Barbárie: o conteúdo do socialismo. São Paulo: Brasiliense, 1983.

COHN-BENDIT, D. O Grande Bazar. As revoltas de 1968, conversas com Michel Lévy, Jean-Marc Salmon e Maren Sell. São Paulo: Brasiliense, 1988.

CUEVA, A. La Concepción Marxista de las Clases Sociales. Debate e Crítica. Revista Quadrimestral de Ciências Sociais. Núm. 03, 1974.

DEBORD, G. A sociedade do espetáculo. Rio de Janeiro: Contraponto, 1997.

LÊNIN, V. Esquerdismo: doença infantil do comunismo. São Paulo: Expressão Paulo, 2014.

GUILlERM, A. \& BOURDET, Y. Autogestão: Mudança Radical. Rio de Janeiro, Zahar, 1976.

GREGOIRE \& PERLMAN. Comitês de ação dos trabalhadores e estudantes. França, maio de 68. Disponível em: <http://libcom.org/library/comit\%C3\%AA-dea\%C3\%A7\%C3\%A3o-de-trabalhadores-e-estudantes> . Último acesso em 08/02/2018.

GROPPO, L. Uma Onda Mundial de Revoltas: Movimentos Estudantis de 1968. Editora UNIMEP: Piracicaba, 2005.

HARVEY, D. Condição Pós-Moderna. São Paulo: Edições Loyola, 1992.

INTERNACIONAL SITUACIONISTA. Teoria e prática da revolução. São Paulo: Conrad, 2002.

JAPPE, A. Guy Debord. Lisboa: Antígona, 2008.

MAKHAISKY, J. Ciência Socialista, A Nova Religião dos Intelectuais. In: TRAGTENBERG, M. (org.). Marxismo Heterodoxo. São Paulo, Brasiliense, 1981.

MANDEL, E. Os intelectuais, os estudantes e a luta de classes. Lisboa: Antídoto, 1979.

MARTINS FILHO, JR. (org.). 1968 faz 30 anos. Campinas: Mercado de Letras, São Carlos: Editora da UFSCAR, 1998.

MARX, K. Contribuição à crítica da economia política. Expressão Popular: São Paulo, 2008.

MARX, K. \& ENGELS, F. A Ideologia Alemã. Editora Boitempo: São Paulo, 2002

SCHAWARZ, P. 1968: A greve geral e a revolta estudantil na França. Disponível em: <https://www.wsws.org/pt/2008/jun2008/port-j23.shtml>. Último acessso: 01/02/2018.

TELES, G. \& FERREIRA, A. Período de Transição ou Contrarrevolução Burocrática? Crítica ao Leninismo e seus desdobramentos históricos. Revista Enfrentamento, ano 12, n. 21: Goiânia, 2017. 
TRAGTENBERG, M. Reflexões sobre o Socialismo. São Paulo: UNESP, 2008.

VIANA, N. Juventude, contestação, autogestão. In: VIANA, N. Juventude e Sociedade: Ensaios sobre a condição juvenil. Giostri: São Paulo, 2015.

O Capitalismo na Era da Acumulação Integral. São Paulo: Ideias e Letras, 2009. Autogestão: O Signo e o Ser. Revista Enfrentamento, ano 8., n.14, jul./dez., 2013. Burocracia: Forma Organizacional e Classe Social. Revista Marxismo e Autogestão, Ano 02, num. 03, jan./jun., 2015.

A Teoria das Classes Sociais em Karl Marx. Florianópolis, Bookess, 2012.

WOODS, A. A Revolução Francesa de Maio de 1968. Revista Marxismo e Autogestão. Ano 03, num. 05, jan./jun. 2016.

Recebido em março de 2018

Aprovado em outubro de 2018 